УДК 343.2/343.8

DOI https://doi.org/10.32837/pyuv.v0i1(30).539

О. В. Ільӥна

orcid.org/0000-0003-4848-3120

кандидат юридичних наук, доцент,

доцент кафедри крилінального права та крилінологї

Київського національного університету ілені Тараса Шевченка

\title{
РЕСОЦІАЛІЗАЦІЯ ЗАСУДЖЕНИХ НЕПОВНОЛІТНІХ, ЯКІ ВІДБУВАЮТЬ ПОКАРАННЯ В МІСЦЯХ НЕСВОБОДИ
}

Кримінальне переслідування, пов'язане із застосуванням легального примусу з боку держави, це один із найдієвіших, але в той же час один із найскладніших засобів підтримання правопорядку в державі. Застосування кримінального покарання призводить до суттєвої зміни способу життя особи, ï діяльності та участі в суспільних процесах. Складність застосування кримінального покарання пов'язана із тим, що воно має бути персональним, виконувати одночасно превентивну, правоохоронну та виховну функцію, а також відповідати характеру злочинного діяння, тобто бути співставним.

Науковці доходять висновку, що основними завданнями виконання покарання у вигляді позбавлення волі неповнолітніх є виправлення, ресоціалізація, перевиховання засуджених, загальна та спеціальна превенція [1, с. 10]. До неповнолітніх як особливої верстви населення застосовуються засоби реабілітації та ресоціалізації. Перш ніж розкрити вказане положення, слід пояснити, що «ідея ресоціалізації засуджених виникла у 80-х pp. XX ст. і знайшла втілення у створенні принципово нової моделі організації покарань, яка отримала назву «реінтеграційна» [2, с. 352]. Вітчизняне кримінально-виконавче законодавство передбачає норму-роз'яснення терміну «ресоціалізація» - свідоме відновлення засудженого в соціальному статусі повноправного члена суспільства; повернення його до самостійного загальноприйнятого соціально-нормативного життя в суспільстві (ч. 2 ст. 6 КВК України) [3].

Зрозуміло, що ресоціалізація має відбуватися щодо кожного засудженого, який став на шлях виправлення. Однак, на думку автора, ресоціалізаційні заходи мають застосуватися з особливим підходом до неповнолітніх через те, що своєчасне вжиття таких заходів впливає на все майбутне життя молодих людей, які опинилися в конфлікті із законом і потребують допомоги.

Так, в Мінімальних стандартних правилах Організації Об’єднаних Націй, які стосуються відправлення правосуддя щодо неповнолітніх («Пекінські правила»), вказано, що «слід приділяти достатню увагу здійсненню позитивних заходів, які передбачають повну мобілізацію всіх можливих ресурсів, включаючи сім'ю, добровольців та інші групи суспільства, а також школи та інші громадські інститути, з метою сприяння благополуччю підлітка, щоб скоротити необхідність втручання з боку закону і ефективного, справедливого й гуманного поводження з підлітком, який перебуває у конфлікті з законом» (п. 1.3.) [4].

Щодо реалізації засад ресоціалізації в українських реаліях, слід вказати на виховну роботу, яка проводиться із засудженими до обмеження волі. Так, «з особами, які відбувають покарання у вигляді обмеження волі, адміністрацією виправного центру, а також власником підприємства, установи, організації або уповноваженим ним органом, де працюють засуджені, і громадськими організаціями проводиться соціально-виховна робота. Активна участь засуджених у виховних заходах заохочується і враховується при визначенні ступеня їхнього виправлення» (ст. 65 КВК України) [3].

3 приводу соціального призначення виховних колоній вчені зазначають, що «найважливішими завданнями виховних колоній, як і виправних, $\epsilon$ належне виконання вироку суду і застосування засобів виправлення та ресоціалізації, основними 3 яких згідно з чинним законодавством є встановлений порядок виконання та відбування покарання (режим), пробація, суспільно-корисна праця, соціально-виховна робота, загальноосвітне і професійно-технічне навчання, громадський вплив. Чинником, який відрізняє виховні колонії від виправних, є пріоритет виховної роботи та навчання вихованців. Водночас у їхній діяльності й досі досить сильно виражена каральна функція, яка розкривається в умовах тримання неповнолітніх. Виховні колонії мають ті самі недоліки, що й кримінально-виконавчі установи. Це зазвичай пояснюється «дорослою» спрямованістю правового регулювання діяльності виховних колоній" $[1$, с. 8].

Здебільшого у місцях позбавлення волі діяльність уповноважених осіб спрямована на виправлення засуджених дорослих осіб, оособливих виправних програм до неповнолітніх осіб майже не застосовується. Однак повинні бути певні відмінності, які мають виявлятися у застосуванні основних засобів виправлення і ресоціалізації, що має виражені виховні та педагогічні аспекти. Проблематика полягає в тому, що форми і методи роботи чітко не регламентовані відомчим законодав- 
ством. Колектив вихователів має право самостійно обирати форми, методики та прийоми провадження виховної роботи залежно від особливостей організації діяльності колонії, іiї розташування, пори року, етнонаціональних особливостей, особливостей категорії засуджених тощо [1, с. 10]. Звісно, тут постає проблема людського фактору та ставлення до своїх професійних обов'язків.

Науковці 3 цього питання зазначають, що «дуже важливою у виховному процесі є чітка взаємодія вчителів школи, вихователів загонів і відділень, викладачів професійного училища, майстрів виробництва. Саме цим забезпечується принцип єдності педагогічних вимог. Однак робота в цьому напрямі $є$ творчою і вимагає створення єдиного навчально-виховного комплексу, який охопить спільною метою всі служби колонії» .

Щодо вимог до сучасних працівників із неповнолітніми, засудженими до покарання, в літературі зазначається, що «для сучасних виховних колоній потрібні висококваліфіковані фахівці, які знають вікову специфіку роботи з неповнолітніми злочинцями. Це насамперед соціальні педагоги, які можуть кваліфіковано визначити ступінь моральної деформації засуджених і розробити відповідні інноваційні заходи" [2, с. 356]. Автор статті вважає, що для належного виконання своїх обов'язків для працівників із неповнолітніми мають бути запроваджені спеціальні курси з підвищення кваліфікації та проведення відбіркових іспитів перед допуском до роботи з неповнолітніми.

Надзвичайно важливим елементом ресоціалізації, виховання та відновлення деформованих кримінально-караним діянням модусів поведінки неповнолітньої особи, на думку автора, є Звіт про неповнолітнього обвинуваченого у кримінальному провадженні щодо неповнолітніх. На виконання так званих Токійських правил 1990 року (Мінімальні стандартні правила $\mathrm{OOH}$ щодо заходів, не пов'язаних із тюремним ув'язненням) та Пекінських правил 1985 року (Мінімальні стандартні правила $\mathrm{OOH}$ щодо відправлення правосуддя стосовно неповнолітніх) вітчизняна судова система внаслідок аналізу, узагальнення та виправлення помилок сучасної вітчизняної практики застосування заходів кримінально-правового характеру щодо неповнолітніх осіб розробила певні рекомендації, які містять важливі аспекти виконання вироків щодо таких осіб.

У своєму листі «Про деякі питання здійснення кримінального провадження щодо неповнолітніх" від 18.07.2013 № 223-1134/0/4-13 Вищий спеціалізований суд України з розгляду цивільних і кримінальних справ зазначив, що «індивідуалізація покарання є важливою вимогою принципового характеру, що передбачає персоніфікацію кримінальної відповідальності: вона настає лише до конкретної особи, яка вчинила злочин (ст. ст. 2, 18, 50 КК України). Тому призначення покарання з урахуванням ступеня тяжкості вчиненого злочину, особи неповнолітнього та обставин, які пом'якшують чи обтяжують покарання, повинно максимально сприяти досягненню мети покарання, яка полягає у виправленні неповнолітнього засудженого, його вихованні та соціальній реабілітації [5].

Цим же листом Вищий спеціалізований суд України з розгляду цивільних і кримінальних справ затвердив форму Звіту, «з урахуванням якого суд у кримінальному провадженні щодо неповнолітнього зможе винести рішення, яке буде відповідати найкращим інтересам неповнолітнього» [5]. Тобто, судові органи, розуміючи проблему ресоціалізації та виховання неповнолітніх навіть у процесі відбування ними покарання, потребують додаткової інформації щодо кожної такої особи, саме так реалізуючи персоналізацію кримінальної відповідальності.

У листі «Про практику здійснення судами кримінального провадження щодо неповнолітніх" від 16.01.2017 № 223-66/0/4-17 Вищий спеціалізований суд України з розгляду цивільних і кримінальних справ зазначив, що «перед ухваленням вироку суду необхідно обов' язково розглянути питання щодо наявності підстав для застосування до неповнолітнього обвинуваченого примусових заходів виховного характеру. В разі обвинувачення неповнолітнього у скоєнні вперше кримінального проступку, злочину невеликої тяжкості або необережного злочину середньої тяжкості правильним вбачається застосовувати за наявності визначених законом умов, незважаючи на відсутність відповідного клопотання прокурора, діючи в порядку, передбаченому ч. 1 ст. 97 КК та ч. 3 ст. 497 КПК України, примусові заходи виховного характеру, звільнивши неповнолітнього від кримінальної відповідальності» [6].

Таким чином, суди не лише намагаються застосовувати ті обмеження та умови при розгляді кримінальних справ щодо неповнолітніх осіб, які закріплені в кримінальному та кримінальнопроцесуальному законодавстві, але й створюють власні акти рекомендаційного характеру, якими розширюють можливості для ресоціалізації та виховання неповнолітніх осіб. При цьому примусове виховання розглядається як один із засобів державного примусу, легітимізуючи одночасно виховну функцію кримінальної відповідальності та систему додаткових гарантій недопущення порушення права неповнолітніх осіб.

Все це демонструє важливий правовий зв'язок між особливим конституційно-правовим статусом неповнолітньої особи, яка має розширене коло прав, зменшене коло обов'язків та додаткові гарантії з боку держави, щодо всебічного розвитку таких осіб. Кримінальне, кримінально-процесу- 
альне та кримінально-виконавче законодавство, яке розроблялося на підставі та з урахуванням конституційних гарантій і конституційних обмежень лише втілює все це в сфері застосування до таких осіб системи легального державного примусу за вчинення ними кримінально караного діяння.

Цінність вказаного правового зв'язку полягає в тому, що за його допомогою в сфері виконання покарання права неповнолітніх осіб забезпечуються максимальним чином, навіть з урахуванням вимог кримінально-виконавчого законодавства, але забезпечення таких прав має на меті продовження розвитку неповнолітньої особи навіть під час відбування нею покарання, що повинно усвідомлюватися як спосіб тиску держави у випадку порушення законності та встановленого правопорядку, що відбувається деперсоніфіковано і застосовується до всіх злочинців. У випадку ж iз неповнолітньюю особою держава лише створює необхідну систему додаткових заходів і засобів забезпечення реалізації прав неповнолітньої особи, що повинно розглядатися як гуманізація покарання та його відбування.

Окремо слід зауважити, що до неповнолітніх застосуються особливі пробаційні заходи. В Законі України «Про пробацію» визначено, що «пробація щодо неповнолітніх - це пробація стосовно осіб віком від 14 до 18 років. Пробація здійснюється з урахуванням вікових і психологічних особливостей неповнолітніх (ч. 1 ст. 12)» [7]. При цьому названий закон не містить виключень щодо застосування видів пробації. Можна стверджувати, що до неповнолітніх осіб можуть застосовуватися всі види пробації: досудова пробація; наглядова пробація; пенітенціарна пробація (ст. 8). Щодо особливостей застосування пробації відносно неповнолітніх осіб слід вказати на такі положення:

1) пробація щодо неповнолітніх здійснюється органом пробації спільно з органами і службами у справах дітей, спеціальними установами та закладами, які здійснюють їх соціальний захист i профілактику правопорушень (ч. 4 ст. 12);

2) орган пробації сприяє залученню засуджених неповнолітніх до навчання та здобуття ними повної загальної середньої освіти (ч. 5 ст. 12);

3) соціально-виховна робота із засудженими неповнолітніми може проводитися із залученням батьків або їхніх законних представників (ч. 6 ст. 12) [7].

Система пробації є тим комплексом заходів, спрямованих на ресоціалізацію неповнолітніх осіб, їх виховання та формування необхідного рівня індивідуальної свідомості, який повинен перетворити їх на повноцінних членів суспільства. Пробація, до якої залучаються спеціалізовані установи та відповідні професіонали в сфері психологічного виховання, психологічного відновлення, покликана забезпечити не тільки відновлення деформованої психіки особи внаслідок вчинення кримінально караного діяння та відбування покарання за нього, але і формування додаткових спеціальних навичок неповнолітніх осіб. Ці навички є необхідними, оскільки неповнолітні особи під час відбування покарання, особливо у вигляді обмеження чи позбавлення волі, вибувають із процесу навчання у загальноосвітніх закладах.

Доведено, що під час відбування покарання неповнолітні особи користуються певними державними гарантіями, які пов'язані з їх віковими обмеженнями щодо виконання низки функцій, зокрема під час реалізації функції праці. Крім того, до неповнолітніх осіб застосовується система державних гарантій і захисту від несанкціонованого застосування заходів фізичного впливу під час виконання вироків, пов'язаних із обмеженням чи позбавленням волі. Це пов'язано з тим, що цілі кримінальної відповідальності пов'язані не лише з усуненням і примусовим перериванням державою кримінально караних діянь і відновленням системи правопорядку, але й і з процесом виховання та запобігання в подальшому виникненню кримінально караних діянь. Виховання неповнолітніх осіб відіграє важливе значення, хоча й може виступати додатковим елементом державного легального примусу. Такі заходи є безальтернативними, оскільки ці особи вибувають зі звичайного для них соціуму.

Розвиток організаційно-правового забезпечення виконання вироків стосовно неповнолітніх осіб повинен відбуватися з урахуванням особливостей суспільної свідомості, правової культури та психологічного стану неповнолітніх осіб. Ресоціалізація таких осіб - це насамперед спосіб формування, а не відновлення, модусу поведінки, яка укладається в допустимі державою межі. Тому вона пов' язана із системою пробації, де з неповнолітніми особами працюють відповідні фахівці, які допомагають створити правильне сприйняття правової реальності та не допустити правову деформацію індивідуальної свідомості неповнолітніх осіб.

\section{Jimepamypa}

1. Стаднік В.В. Виконання покарання у вигляді позбавлення волі щодо неповнолітніх : автореф. дис. ... канд. юрид. наук: 12.00.08. Львів, 2018. 23 с.

2. Яцишин Ю.М. Сучасний вітчизняний і міжнародний інноваційний досвід ресоціалізації неповнолітніх засуджених. Міжнародний науковий вісник : збірник наукових статей за матеріалали XXVII Міжнародної науково-практичної конферениї, Ужгород-Будапешт, 26-29 листопада 2013 р. / ред. кол. В.І. Смоланка (голова), І.В. Артьомов та ін. Ужгород : ДВНЗ «УжНУ , 2014. Вип. 8(27). С. 352-357.

3. Кримінально-виконавчий кодекс України. Відомості Верховної Ради Украӥни. 2004. № 3-4. Ст. 21.

4. Мінімальні стандартні правила Організації Об'єднаних Націй, які стосуються відправлення правосуддя щодо неповнолітніх («Пекінські правила»). 
URL: https://zakon.rada.gov.ua/laws/main/995 211 (дата звернення: 23.11.2019).

5. Про деякі питання здійснення кримінального провадження щодо неповнолітніх : Лист Вищого спеціалізованого суду від 18.07.2013 № 223-1134/0/4-13. URL: https://zakon.rada.gov.ua/laws/show/v1134740-13.

6. Про практику здійснення судами кримінального провадження щодо неповнолітніх : Лист Вищого спеціалізованого суд України з розгляду цивільних і кримінальних справ від 16.01.2017 № 223-66/0/4-17. URL https://ips.ligazakon.net/document/VRR00215.

7. Про пробацію : Закон України від 05.02.2015 p. № 160-VIII. Відомості Верховної Ради. 2015. № 13. Ст. 93.

\section{Анотація}

Ільӥна О. В. Ресоціалізація засуджених неповнолітніх, які відбувають покарання в місцях несвободи. Стаття.

У статті проаналізовано організаційно-правове забезпечення виконання вироків стосовно неповнолітніх осіб. Застосування кримінального покарання, а також виконання вироків суду стосовно неповнолітніх осіб є одним із найскладніших елементів кримінально-правового захисту суспільних відносин. Неповнолітні особи мають специфічне кримінально-правове становище, зумовлене їхнім віком, рівнем індивідуальної правової свідомості, рівнем психологічної стійкості та правової культури. Все це має визначальний вплив на формування особистості, а також на ставлення неповнолітньої особи до скоєного злочинного діяння.

Основним завданням кримінальної відповідальності стає не лише покарання, але й виправлення модусу поведінки неповнолітньої особи. 3 цих позицій пошук особливостей організаційно-правового забезпечення виконання вироків стосовно неповнолітніх осіб, пов'я заний із теоретико-методологічним забезпеченням можливих шляхів підвищення ефективності та дієвості виконання вироків щодо таких осіб, має ще й суспільну необхідність. Останнє пояснюється тим, що для держави важливим $€$ формування генофонду нації, основним потенціалом для чого і є молодь. Тому виконання вироків щодо неповнолітніх осіб не повинно створювати в них відчуття асоціалізації, викреслення державою їх із нормального суспільного життя.

Додатковою слід зазначити, що через контекст пошуку ефективних, однозначних і змістовних, навіть вичерпних способів викладення нормативно-правового закріплення механізму виконання вироків суду стосовно неповнолітніх осіб підвищуватиметься якість виконання функцій держави щодо забезпечення належного рівня прав осіб навіть у процесі виконання вироків щодо них.

Сучасна вітчизняна пенітенціарна система об'єктивно характеризується низьким рівнем дотримання вимог законодавства в сфері виконання вироків через брак фінансування, недостатній рівень компетенції працівників системи виконання покарань тощо. Держава повинна забезпечувати належний рівень ор- ганізаційно-правового забезпечення процесу виконання вироків, особливо щодо неповнолітніх осіб. Через це пошук особливостей такого забезпечення, проведений в межах цього дослідження, супроводжується виділенням найслабших місць практичного виконання вироків стосовно вказаного кола осіб.

Ключові слова: неповнолітні особи, організаційно-правове забезпечення, виконання вироків, позбавлення волі, ресоціалізація, пробація.

\section{Summary}

Ilina $0 . V$. The resocialization of convicted juveniles serving their sentences in prisons. - Article.

The article analyzes the organizational and legal support of the execution of sentences against minors. The use of criminal penalties as well as the enforcement of juvenile court sentences is one of the most difficult elements of criminal defense of public relations. Juveniles have a specific criminal status due to their age, level of individual legal consciousness, as well as the level of psychological stability and legal culture. All this has a decisive influence on the formation of the individual, as well as the attitude of the minor to the criminal act. Therefore, the main task of criminal responsibility is not only the punishment, but also the correction of the mode of behavior of a minor.

From these perspectives, the search for the peculiarities of the legal and legal support for the execution of sentences against minors is directly related to the theoretical and methodological provision of possible ways of improving the efficiency and effectiveness of the execution of sentences against such persons is also a public necessity. The latter is explained by the fact that for the state it is important to form a gene pool of the nation, the main potential for which the youth stands. From such execution of sentences against minors should not create in them a feeling of association, their removal from normal social life by the state.

It should be noted that the context of the search for effective, unambiguous and meaningful, even comprehensive ways of explaining the legal framework for the execution of court sentences against minors, will improve the quality of the state's functions to ensure the proper level of rights of persons, even in the process of executing sentences against them. The current domestic penitentiary system is objectively characterized by a low level of compliance with the requirements of the law in the sphere of execution of sentences due to lack of funding, insufficient level of competence of the employees of the system of punishment enforcement, etc.

The state must ensure an adequate level of legal support for the execution of sentences in general, and especially for minors. Therefore, the search for the features of such security that will be undertaken in the framework of this study should be accompanied by the identification of the weakest points of practical enforcement of sentences against the specified circle of persons.

Key words: juvenile persons, legal support, execution of sentences, imprisonment, resocialization, probation. 